Table $5 a$.

Distribution of Papers Accepted, by Field, 2008-09 (\%)

FIELD

\begin{tabular}{cccccccc}
\hline American Politics Comparative Politics & $\begin{array}{c}\text { International } \\
\text { Relations }\end{array}$ & $\begin{array}{c}\text { Normative } \\
\text { Theory }\end{array}$ & $\begin{array}{c}\text { Formal } \\
\text { Theory }\end{array}$ & Methods & $\begin{array}{c}\text { Race, Ethnicity, and } \\
\text { Politics }\end{array}$ & \begin{tabular}{c} 
Other \\
\hline 21
\end{tabular} \\
\hline 26 & 17 & 24 & 10 & 0 & 2 & 0 \\
\hline
\end{tabular}

Table $5 b$.

Distribution of Papers Accepted, by Approach, 2008-09 (\%)

APPROACH

\begin{tabular}{cccccc}
\hline Formal & Quantitative & Formal and Quantitative & Small N & Interpretive/Conceptual & Other \\
\hline 5 & 59 & 12 & 0 & 24 & 0 \\
\hline
\end{tabular}

We believe that our efforts to attract and publish manuscripts across all subfields in the discipline have borne fruit. At the same time, we exert our greatest efforts to make sure that as many articles as possible that appear in the Review are comprehensible by and of interest to a broad spectrum of political and other social scientists. Our primary aim remains that of stimulating conversation

and inquiry among the broad community

that is political science.

\section{NOTES}

1. In the brief period in early 2009 when we had four

EAs, the time from receipt to editor assignment fell

to about 10 days.

\title{
Congressional Fellowship Program 2009-2010 Office Assignments
}

$\mathrm{F}$ ounded in 1953, the APSA Congressional Fellowship Program is the nation's oldest and most prestigious congressional fellowship. More than 50 years later, the program remains devoted to its original objective of expanding knowledge and awareness of Congress. For nine months, select political scientists, journalists, doctors, federal executives, and international scholars gain "hands on" understanding of the legislative process by serving on congressional staffs. Through this unique opportunity, the association enhances public understanding of policymaking and improves the quality of scholarship, teaching, and reporting on American national politics. For more information, please visit www.apsanet.org/content_3031.cfm?navID=41. The 2010 office assignments are:

\section{U.S. SENATE}

Jason Ackleson, Ph.D.

Sen. Jeff Bingaman (D-NM)

Courtney Cooper

Sen. Blanche Lincoln (D-AR)

Amy K. DiRusso

Sen. Benjamin L. Cardin (D-MD)

Lee Drutman, Ph.D.

Sen. Robert Menendez (D-NJ)

Sheldon D. Fields, Ph.D.

Sen. Barbara Mikulski (D-MD)

Laura Kosch

Sen. Mike Johanns (R-NE)

Gregory Margolis, Ph.D.

Sen. John Rockefeller (D-WV)
Daniel K. Schill, Ph.D.

Sen. Amy Klobuchar (D-MN)

Beth Ward

Sen. Debbie Stabenow (D-MI)

\section{U.S. HOUSE OF REPRESENTATIVES}

Nancy Berson

Rep. Charles Rangel (D-NY)

B. Welling Hall, Ph.D. Rep. Keith Ellison (D-MN)

\section{Sarah Han}

Rep. Bob Inglis (R-SC)

Ulrike Hornung, LL.M.

Rep. Linda T. Sanchez (D-CA)

Sang-hun Lee
Rep. Jim McDermott (D-WA)

Stacia Martin

Rep. Kurt Schrader (D-OR)

Rebecca Thorpe

Rep. James Oberstar (D-MN)

Torsak Janpian

Del.Eni F. H. Faleomavaega (D-American Samoa)/House Committee on Foreign Affairs, Subcommittee on Asia, the

Pacific and the Global Environment

\section{LEADERSHIP OFFICES}

Margaret Wilmoth, Ph.D.

Office of the Speaker

Katrina Gamble, Ph.D. 
Office of the House Majority Whip

Kathleen Negri

House Democratic Caucus Seniors' Taskforce

\section{COMMITTEES}

Andrew Bindman, MD

House Committee on Energy and Commerce

Diane Meier, MD

Senate Committee on Health, Education, Labor and Pensions (HELP)

Sonja Regler

House Committee on Foreign Affairs, Subcommittee on Africa and Global Health/Rep. Donald Payne (D-NJ) Walt Jatkowski, Ph.D.

House Committee on Oversight and Gov- ernment Reform (Minority)

Mark D. Schwartz, MD

House Committee on Ways and Means, Subcommittee on Health

\section{EXECUTIVE BRANCH}

Janet Leigh, MD

Office of the Assistant Secretary for Preparedness and Response (ASPR)

Charles (Chad) Boult, MD

Centers for Medicare and Medicaid Services (CMS)

Barbara B. Tobias, MD

Department of Health and Human Services, Office of the Secretary, Office of the Chief of Staff/Counselor for Public Health and Science

Gustavo Gruz, MD
Department of Health and Human Services, Office of the HHS Secretary, working directly with the Counselor's Office

Kelly Horton, MS, RD, CD

Department of Agriculture, Food and Nutrition Services' Office of Strategic Initiatives and Partnerships

David Keller, MD

Department of Health and Human Services, Office of the Assistant Secretary for Planning and Evaluation (ASPE)

Shale Wong, MD

Office of the First Lady Michelle Obama, Initiative to Reduce Childhood Obesity

\title{
APSA Names 2010-2011 Minority Fellows
}

\begin{abstract}
n recognition of their outstanding academic and personal achievements, APSA is pleased to announce the APSA Minority Fellows for the 2010-2011 academic year. The Minority Fellows Program (MFP) was established in 1969 as an effort to increase the number L of minority scholars in the discipline, and has designated more than 400 fellows and contributed to the successful completion of doctoral political science programs for over 100 individuals. APSA has refocused and increased its efforts to assist minority students in completing their doctorates by concentrating not only on the recruitment of minorities, but also on the retention of these groups within the profession. The MFP designates up to 12 stipend minority fellows each year. Fellows with stipends receive a $\$ 4,000$ fellowship that is disbursed in two \$2,00o payments-one at the end of their first graduate year and one at the end of their second-provided that they remain in good academic standing. Awards are based on students' undergraduate course work, GPA, extracurricular activities, GRE scores, and recommendations from faculty. Members of the selection committee for this year's fellows included Ben Marquez, Committee on the Status of Latinos and Latinas in the Profession; Alice Jackson, Committee on the Status of Blacks in the Profession; and Ann Chih Lin, chair of the Committee on Asian Pacific Americans in Political Science. Learn more about the program by visiting http://www.apsanet. org/content_3284.cfm. This year's Minority Fellows are:
\end{abstract}

Edgar Alfonseca is a current Ronald E. McNair Scholar at Binghamton University. He recently conducted research through the McNair Summer Research internship pertaining to civil wars and external interventions. As an undergraduate student, he worked for the Translation Research and Instruction Program as a Federal Work-Study Stu-

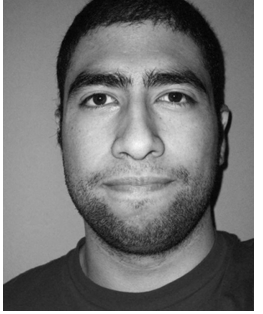
dent. Mr. Alfonseca served as an intern for the Career Development Center at Binghamton University. He was awarded the Michael V. Boyd Memorial Scholarship and Faculty Student Scholarship for the 2009-2010 year at Binghamton University.
Jesse Atencio is a senior at Washington University in St. Louis, majoring in political science. He attended the 2009 Ralph Bunche Summer Institute and pre-

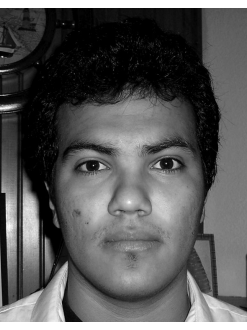
sented his research paper at the APSA Annual Meeting in Toronto. Mr. Atencio became interested in political theory during his sophomore year, particularly after being introduced to St. Augustine's City of God. Mr. Atencio plans to undertake a $\mathrm{Ph} . \mathrm{D}$. program in political science to bring the human experience back into the discipline by focusing on concepts such as identity, recognition, and existential choice, and their implications for liberalism.
Parris Baker is currently a senior at the University of Florida. During his collegiate career, he has earned many awards and honors. While at Valencia Community College, his academic excellence garnered him many appearances on the President's List. His commitment to academics continues at the University of Florida, where he earned a transfer scholarship, a multicultural award, and admission into the Ronald E. McNair Scholars Program. As a McNair scholar, he is studying the role that hip-hop played in influencing discourse during the 2008 presidential election. His research interests include political theory, political behavior, and hip- 